This document is confidential and is proprietary to the American Chemical Society and its authors. Do not copy or disclose without written permission. If you have received this item in error, notify the sender and delete all copies.

\title{
Variability in disinfection resistance within an between currently circulating Enterovirus B serotypes
}

\begin{tabular}{|r|l|}
\hline Journal: & Environmental Science \& Technology \\
\hline Manuscript ID & es-2018-008516 \\
\hline Manuscript Type: & Article \\
\hline Complete List of Authors: & $\begin{array}{l}\text { Meister, Simon; Ecole Polytechnique Federale de Lausanne, Environmental } \\
\text { Engineering Institute } \\
\text { Verbyla, Matthew; Ecole Polytechnique Federale de Lausanne, } \\
\text { Environmental Engineering Institute } \\
\text { Klinger, Marius; Ecole Polytechnique Federale de Lausanne, Environmental } \\
\text { Engineering Institute } \\
\text { Kohn, Tamar; Ecole Polytechnique Federale de Lausanne, Environmental } \\
\text { Engineering Institute }\end{array}$ \\
\hline
\end{tabular}




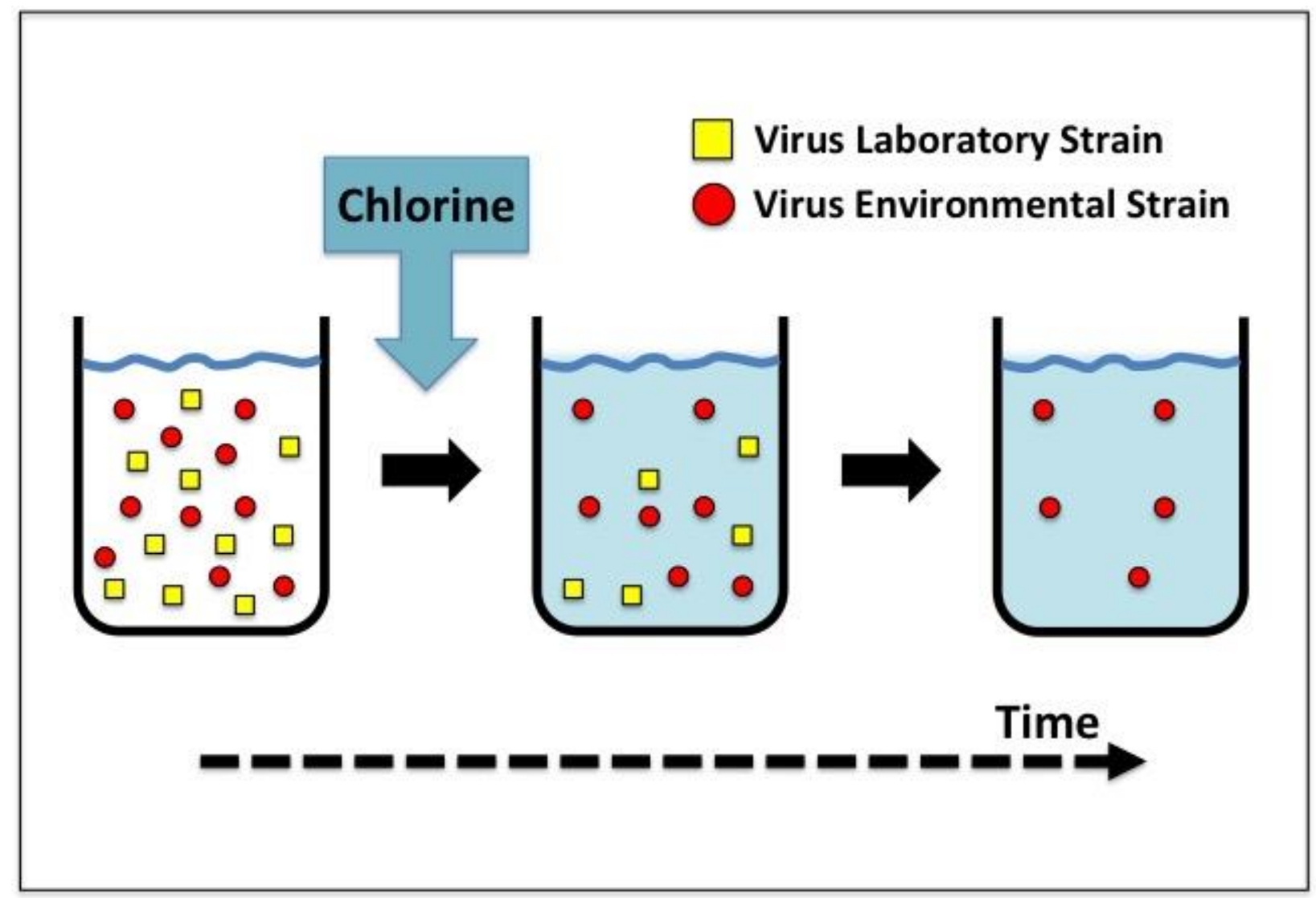




\title{
Variability in disinfection resistance within an between currently circulating Enterovirus B serotypes
}

\author{
Simon Meister ${ }^{1}$, Matthew E. Verbyla ${ }^{1,2}$, Marius Klinger ${ }^{1}$, Tamar Kohn ${ }^{1 *}$
}

${ }^{1}$ Laboratory of Environmental Chemistry, School of Architecture, Civil and Environmental Engineering, École Polytechnique Fédérale de Lausanne (EPFL), $\mathrm{CH}$ 1015 Lausanne, Switzerland

${ }^{2}$ Current affiliation: Department of Civil, Construction, and Environmental Engineering, San Diego State University, San Diego, California, USA

* To whom correspondence should be addressed: e-mail: tamar.kohn@epfl.ch; phone: +41216930891 


\section{ABSTRACT}

2 The susceptibility of waterborne viruses to disinfection is known to vary between viruses and even

3 between closely related strains, yet the extent of this variation is not known. Here, different

4 enteroviruses (six strains of coxsackievirus B5, two strains of coxsackievirus B4 and one strain of

5 coxackievirus B1) were isolated from wastewater and inactivated by $\mathrm{UV}_{254}$, sunlight, free chlorine

$6(\mathrm{FC})$, chlorine dioxide $\left(\mathrm{ClO}_{2}\right)$, and heat. Inactivation kinetics of these isolates were compared with

7 those of laboratory enterovirus strains (CVB5 Faulkner and echovirus 11 Gregory) and MS2

8 bacteriophage. FC exhibited the greatest (10-fold) variability in inactivation kinetics between

9 different strains, whereas inactivation by $U V_{254}$ differed only subtly. The variability in inactivation kinetics was greater between serotypes than it was among the seven strains of the CVB5 serotype.

11 MS2 was a conservative surrogate of enterovirus inactivation by $U_{254}$, sunlight or heat, but

12 frequently underestimated the disinfection requirements for $\mathrm{FC}$ and $\mathrm{ClO}_{2}$. Similarly, laboratory strains

13 did not always reflect the inactivation behavior of the environmental isolates. Overall, there was

14 considerable variability in inactivation kinetics among and within enteroviruses serotypes, as well as

15 between laboratory and environmental isolates. We therefore recommend that future disinfection

16 studies include a variety of serotypes and environmental isolates. 


\section{INTRODUCTION}

Human enteric viruses are a leading cause of waterborne disease worldwide ${ }^{1}$. Their control remains problematic; compared to bacterial pathogens and fecal indicators, viruses are highly persistent in the environment ${ }^{2}$ and have high resistance to disinfectants such as chlorine ${ }^{3}$. The Enterovirus genus of the Picornaviridae family in particular is a major source of the waterborne disease burden ${ }^{4}$ and hence it is included on the EPA contaminant candidate list (EPA, CCL4 ${ }^{5}$ ). Within this genus, species of concern include Enterovirus A, which contains coxsackievirus A serotypes, Enterovirus $B$, which includes serotypes of echovirus and coxsackievirus B, and Enterovirus $C$, which includes poliovirus and other coxsackievirus A serotypes ${ }^{6,7}$.

Serotypes of the Enterovirus genus are generally more resistant than other enteric viruses to chlorine $^{8,9}$. The different species and serotypes of this genus, however, have a wide range of susceptibilities to disinfection. For example, differences in chlorine resistance were observed between the serotypes coxsackievirus B4 (CVB4) and B5 (CVB5), as well as poliovirus serotypes (PV) 1, 2 and $3^{10}$, with CVB5 displaying the highest resistance. Similarly, disinfection by monochloramine exhibited up to three-fold greater inactivation rates of serotypes coxsackievirus B3 (CVB3) compared to CVB5, and more than 100-fold greater rates for serotypes echovirus 1 compared to echovirus 11 $(\mathrm{E} 11)^{9}$. Finally, disinfection of wastewater effluent by chlorine dioxide $\left(\mathrm{ClO}_{2}\right)$ revealed that CVB5 was more resistant than echovirus 1 and PV 1 serotypes ${ }^{11}$. More surprisingly, differences were also observed among strains of the same poliovirus serotype ${ }^{12,13}$, revealing variability even among closely related viruses. Combined, these studies indicate that differences in resistance to oxidizing disinfectants exists between the different Enterovirus species, between serotypes and even within serotypes. In contrast, similar susceptibility was found among different enteroviruses to UV light and sunlight $^{14,15}$.

The reason for variability in Enterovirus susceptibility to oxidants is not well understood, yet it may be driven through selection by the disinfectant for the most resistant variants. For example Bates et 
43

44

45

al. ${ }^{16}$ demonstrated that the repeated exposure of PV to chlorine led to increased resistance. Similarly, Shaffer et al. ${ }^{17}$ reported that PV isolated from chlorinated drinking water were more resistant to chlorine than unexposed lab strains. More recently, our group has repeatedly exposed echovirus 11 to $U V_{254}$ which resulted in the selection of $U_{254}$-resistant strains. Similarly, repeated exposure of echovirus 11 to $U V$ light at $254 \mathrm{~nm}\left(\mathrm{UV}_{254}\right)$ led to the selection of $U_{254}$-resistant strains ${ }^{18}$. Selection of disinfection-resistant viruses may also arise from exposure to environmental stressors. Specifically, Payment et al. ${ }^{10}$ demonstrated that sewage isolates of CVB5 were more resistant to chlorine compared to the corresponding lab strains. Tree et al. ${ }^{19}$ furthermore demonstrated that sewageborne PV were more resistant to chlorination compared to lab strains.

To establish adequate disinfection practices, it is important that the diversity in disinfection kinetics of circulating viruses is taken into account. To this end, we isolated nine strains of Enterovirus $B$ from untreated domestic sewage from three geographic locations (Lausanne, Switzerland, Minneapolis, $\mathrm{MN}$ and Tampa, $\mathrm{FL}$ ), and compared their disinfection kinetics with those of two laboratory strains (echovirus 11 Gregory strain and coxsackievirus B5 Faulkner strain). Additionally, inactivation kinetic parameters were compared to those of MS2 bacteriophage, which has been proposed as a surrogate for enteric viruses for the assessment of household water treatment interventions (including chlorination, UV, solar disinfection, and heat treatment) ${ }^{20}$. All viruses were subjected to inactivation by five different treatments of which two mainly act by inducing genome damage $\left(U_{254}\right.$ and simulated sunlight), two target both the viral genome and proteins $\left(\mathrm{FC}\right.$ and $\left.\mathrm{ClO}_{2}\right)$, and one (heat) induces non-oxidative protein denaturation ${ }^{21}$. The ultimate objective of this study was to quantify the extent of variability in disinfection resistance for different Enterovirus B serotypes and strains, as well as for different inactivation methods, and to assess if surrogate viruses can be used to represent the inactivation of circulating viruses. 
EXPERIMENTAL SECTION

70

71

\section{Chemicals, virus laboratory strains and cells}

The sources of all chemicals, virus laboratory strains and their host cells is given in the Supporting Information.

\section{Isolation of circulating viruses}

Viruses were isolated from one liter of untreated domestic sewage from three wastewater treatment plants (Lausanne, Switzerland, Minneapolis, MS, and Tampa, FL), as described previously ${ }^{22-25}$. Insoluble contaminants were removed by adding $110 \mathrm{~mL}$ of glycine buffer $(1 \mathrm{M}$ glycine, $3 \mathrm{M} \mathrm{NaCl}$, miliQ $\mathrm{H}_{2} \mathrm{O}, \mathrm{pH} 9.5$ ), stirring on ice for $20 \mathrm{~min}$, and then centrifuging for $30 \mathrm{~min}$ at $6700 \times \mathrm{g}$ at $4^{\circ} \mathrm{C}$. The supernatant was transferred to a clean bottle, the $\mathrm{pH}$ was adjusted to 7.2 with $\mathrm{HCl}, 200 \mathrm{~mL}$ of polyethylene glycol (PEG) $8000(40 \%)$ were added and samples were stirred overnight at $4^{\circ} \mathrm{C}$. Samples were then centrifuged for $40 \mathrm{~min}$ at $4^{\circ} \mathrm{C}$, then the supernatant discarded and the pellet was resuspended in $15 \mathrm{~mL}$ of phosphate-buffered saline (PBS; $5 \mathrm{mM} \mathrm{NaH} \mathrm{PO}_{4}, 10 \mathrm{mM} \mathrm{NaCl}$, pH7.4). To remove PEG and macromolecular inhibitors, the solution was vigorously mixed with $15 \mathrm{~mL}$ chloroform and centrifuged for $15 \mathrm{~min}$ at room temperature. The upper phase was harvested, filtered through a $0.45 \mu \mathrm{m}$ filter (hydrophilic polyethersulfone filter; Millipore), and concentrated to $1.7 \mathrm{~mL}$ using an Amicon $100 \mathrm{kDa}$ molecular weight cutoff column (Sigma-Aldrich, Germany). Buffalo Green Monkey Kidney (BGMK) cells were grown to confluence in T25 flasks (TPP Techno Plastic Products, Trasadingen, Switzerland) as described previously ${ }^{26}$, were infected with the concentrated viruses diluted in cell culture media (see SI) at a 1:10 ratio, and the cytopathic effect (CPE) was checked daily. After full CPE was observed (around four days post-infection), the cell lysate was harvested and viruses were clarified by centrifugation. Finally, two successive plaque assays were performed to isolate individual virus strains (see SI for details). 


\section{Virus identification, whole genome sequencing and alignment}

94

To identify the virus serotypes isolated, general enterovirus Inosine-degenerated primers targeting the viral protein 1 (VP1) were used ${ }^{27}$. The PCR amplicon size was first checked by agarose gel, then sequenced by Sanger technique using the same primers. The resulting sequences were identified by the NCBI basic local alignment search tool (BLAST). Whole genome sequencing of the CVB5 isolates was accomplished by aligning 86 CVB5 complete genomes listed in the ViPR ${ }^{28}$ database. Primer couples were designed along the consensus sequence and used to sequence the whole genome of each isolate (Table S1). CVB4 isolates were sequenced with primers designed according to a single CVB4 sequence (accession number: $S 76772^{29}$ ), and CVB1 was sequenced with CVB1-derived primers. Based on the initial sequencing results, additional strain-specific primers were designed to complete genome sequences not fully captured by these serotype-specific primers. Virus genome sequences were checked, aligned, assembled, and annotated using the Geneious software version 8.1.8 ${ }^{30}$.

The whole sequence of VP1 was used to align the different viruses and calculate their pairwise identity using multiple sequence comparison by log-expectation (MUSCLE) $)^{31}$ with an iteration of 8 , a gap open penalty of 400 , and a gap extension penalty of 0 . An unrooted tree was built using the neighbor-joining estimation method ${ }^{32}$. The protein pairwise identity was determined using the translated region of the structural proteins (VP1 to VP4).

\section{Virus purification and enumeration}

To prepare viral stock solutions, each strain was individually amplified in BGMK cells, purified by PEG precipitation and chloroform treatment ${ }^{33}$, concentrated, and divided into aliquots of $100 \mu \mathrm{L}$. At least two stock solutions from separate amplifications were produced for each virus. Viruses in all stock solutions were analyzed by dynamic light scattering as described previously ${ }^{34}$ and were found to be monodispersed (data not shown). Infective virus concentrations were determined by endpoint dilutions with Most Probable Number (MPN) statistics ${ }^{35}$, and are reported as most probable number 
117 of cytopathic units per $\mathrm{mL}\left(\mathrm{MPNCU} \cdot \mathrm{mL}^{-1}\right)$. Endpoint dilutions were performed on BGMK cells in 96-

118 well plates, with five replicates and eight dilutions per experimental sample. After inoculation, plates 119 were incubated at $37^{\circ} \mathrm{C}$ with $5 \% \mathrm{CO}_{2}{ }^{26}$, and the presence or absence of $\mathrm{CPE}$ in each well was 120 determined five days post-infection through microscopy. MS2 bacteriophage was propagated, 121 purified by PEG and chloroform, and enumerated using the double agar layer plaque assay method 122 as described previously ${ }^{33}$, and its infectivity was measured in plaque forming units per $\mathrm{mL}\left(P F U \cdot \mathrm{mL}^{-1}\right)$.

Inactivation experiments

124

125

126
Inactivation experiments were performed two to four times per virus and disinfectant, and eight samples were taken to construct each inactivation curve. All experiments were performed in PBS at an initial virus concentrations of $10^{7}$ to $10^{8} \mathrm{MPNCU} \cdot \mathrm{mL}^{-1}$ or PFU $\cdot \mathrm{mL}^{-1}$.

$U V_{254}$. A low-pressure monochromatic UVC lamp was used to test the virus inactivation at a wavelength of $254 \mathrm{~nm}\left(\mathrm{UV}_{254}\right)$. A bench scale device containing a $17 \mathrm{~W}$ mercury UV lamp (Philips, TUV F17T8) with a manual shutter was used. Two $\mathrm{mL}$ of PBS were added to a darkened glass beaker, were spiked with viruses, and were exposed to $U^{254}$ for up to four minutes under constant stirring. Aliquots of $100 \mu \mathrm{L}$ were harvested every thirty seconds. The $\mathrm{UV}_{254}$ fluence rate was measured by iodide/iodate actinometry ${ }^{36,37}$, and corresponded to $1.398 \mathrm{~W} \cdot \mathrm{m}^{-2}$.

Simulated sunlight. Sunlight was simulated using Sun 2000 (Abet Technologies) equipped with a 1000W Xenon lamp, an AirMass 1.5 filter, and a $2 \mathrm{~mm}$ atmospheric edge filter. The irradiance spectrum was determined using a radiometer (ILT 900-R; International Light Technologies, Peabody, MA). The average UVB fluence rate was calculated by integrating the irradiance from 280 to $320 \mathrm{~nm}$ and corresponded to $0.563 \mathrm{~W} \cdot \mathrm{m}^{-2}$. For typical 12-hour day exposure, this corresponds to four times the equatorial UVB fluence determined elsewhere ${ }^{38} .100 \mu \mathrm{L}$ of virus concentrate were added to 10 $\mathrm{mL}$ of PBS in a glass beaker immersed in a $22^{\circ} \mathrm{C}$ temperature-controlled water bath, and were exposed to simulated sunlight under constant stirring. Samples of $100 \mu \mathrm{L}$ were taken each 2-3 hours over the course of up to 24 hours. 
142 Free chlorine. Prior to experiments, $10 \mathrm{~mL}$ glass beakers were incubated overnight in a concentrated

143 FC solution to quench any chlorine demand. The FC working solution was prepared by diluting bleach 144 solution $(15 \% \mathrm{HOCl})$ in PBS to a final concentration between 0.8 and $3.1 \mathrm{mg} \cdot \mathrm{L}^{-1}$. The FC concentration 145 was measured by the N,N-diethyl-p-phenylenediamine colorimetric method ${ }^{39}$ at the beginning and 146 end of each experiment, and typically varied by less than $20 \%$ throughout the experiment. Therefore 147 the average of the initial and final FC concentration in each experiment was considered as the 148 working concentration. Prior to each experiment, beakers were rinsed twice with the working solution. Then $50 \mu \mathrm{L}$ of virus stock solution were spiked into a $2 \mathrm{~mL}$ working solution under constant stirring. $10 \mu \mathrm{L}$ aliquots were harvested every 10-30 seconds over the course of 3 minutes, and were directly mixed with $90 \mu \mathrm{L}$ PBS containing $1.4 \mathrm{M}$ sodium thiosulfate to quench the residual FC. The initial virus concentration was sampled from a $2 \mathrm{~mL}$ PBS solution without FC, spiked with $50 \mu \mathrm{L}$ virus stock.

Chlorine dioxide. A concentrated $\mathrm{ClO}_{2}$ solution was obtained by mixing $100 \mathrm{~mL} 4 \% \mathrm{~K}_{2} \mathrm{~S}_{2} \mathrm{O}_{8}$ with $100 \mathrm{~mL}$ $2 \% \mathrm{NaClO}_{2}$ as described elsewhere ${ }^{40}$, and was kept at $4{ }^{\circ} \mathrm{C} . \mathrm{ClO}_{2}$ concentrations were measured by spectrophotometer (UV-2550; Shimadzu) at $358 \mathrm{~nm}$. The concentrated solution was mixed with PBS in order to obtain a supply solution $\left(4-7 \mathrm{mg} \cdot \mathrm{L}^{-1}\right)$ and a working solution $\left(0.25-1 \mathrm{mg} \cdot \mathrm{L}^{-1}\right)$. All beakers were rinsed three times with the working solution. Then $2 \mathrm{~mL}$ of working solution were amended with $50 \mu \mathrm{L}$ of virus stock solution under constant stirring. Throughout the experiment, the $\mathrm{ClO}_{2}$ concentration was maintained approximately constant $( \pm 7 \%$ ) by continuously adding the supply solution with a syringe pump at a flow rate of 5-20 $\mu \mathrm{L} \cdot \mathrm{min}^{-1}$. The sampling procedure, $\mathrm{ClO}_{2}$ quenching, and measurement of the initial virus concentration were performed as described for FC.

Heat. Inactivation experiments by heat were performed in a PCR thermocycler (Applied Biosystems, GeneAmp PCR system 9700). PCR tubes containing $90 \mu \mathrm{L}$ of PBS were heated to $55^{\circ} \mathrm{C}$, then $10 \mu \mathrm{L}$ of virus stock solution was spiked into each tube. At each time point, a sample was removed and quickly 
placed in an aluminium PCR cooling block on ice. The initial virus concentration was measured by

167 spiking $10 \mu \mathrm{L}$ of viruses in $90 \mu \mathrm{L}$ of PBS at room temperature.

168

169

170

171

172

$173 \quad \frac{\partial N}{\partial t}=-k C^{\eta} N$

Given that $C$ was approximately constant in our experimental systems, the integration of Equation 1

175 gives the following,

176

$N=N_{o} \mathrm{e}^{-k C t}$

(equation 2)

177 where $C t$ is the dose, and the inactivation rate constants $(k)$ have the units $\mathrm{mJ}^{-1} \cdot \mathrm{cm}^{2}\left(\right.$ for $\mathrm{UV}_{254}$ and 178 sunlight), and $\mathrm{mg}^{-1} \cdot \mathrm{min}^{-1} \cdot \mathrm{L}($ for $\mathrm{FC})$.

179 Infectivity loss by $\mathrm{ClO}_{2}$ and heat were modeled by segmental regression, according to the following 180 equation,

$181 \quad N=N_{o} \mathrm{e}^{-k 1 C t}+N_{1} \mathrm{e}^{-k 2 C t}$

(equation 3)

182

183

184

185

186

187

where $\mathrm{N}_{1}$ is the breakpoint (the virus concentration at which kinetics deviate from the initial exponential decay), and $k_{1}$ (hereafter denoted as $k_{\mathrm{ClO} 2}$ or $k_{\text {heat }}$ ) and $k_{2}$ are the rate constants associated with inactivation before and after the breakpoint. Here, $C t$ is the dose in $\mathrm{mg} \cdot \mathrm{min} \cdot \mathrm{L}^{-1}$ for $\mathrm{ClO}_{2}$ and seconds at $55{ }^{\circ} \mathrm{C}$ for heat. The inactivation rate constants $k_{\mathrm{ClO} 2}$ and $k_{\text {heat }}$ have units of $\mathrm{mg}^{-}$ ${ }^{1} \cdot \mathrm{min}^{-1} \cdot \mathrm{L}$ and $\mathrm{s}^{-1}$, respectively.

\section{Bayesian analysis of rate constants}


188 The probabilities associated with the values of $k$ were estimated using Bayesian inference (see 189 Supporting Information for details). The probability of one virus strain or serotype being more or less 190 resistant than another was calculated as the difference between the posterior distributions of the 191 two inactivation rate constants. Bayesian inference was used instead of conventional hypothesis 192 testing (e.g., with p-values and confidence intervals) to provide a more intuitive assessment of the 193 probabilities that a given virus has an inactivation rate constant, and hence a disinfection resistance, 194 that differs from a reference virus considered (e.g., CVB5 Faulkner strain). Furthermore, the use of 195 Bayesian inference allows for the reduction of uncertainty in the rate constant by utilizing raw endpoint dilution data (number of positive wells in a given dilution sample) directly in a likelihood model $^{43}$, instead of using MPN estimates at different dose levels as inputs to fit a log-linear inactivation curve using the least squares method. For the comparison of serotypes, $k$ distributions of all viruses of a given serotype were combined and $30^{\prime} 000$ values were randomly sampled from the resulting mixture distribution. These values were then used to calculate posterior distribution differences.

\section{Data analysis}

All computations of kinetic parameters and pairwise identities were performed in $\mathrm{R}^{44}$, supplemented with JAGS for Bayesian analysis ${ }^{45}$. The following CRAN packages were used: ggplot $2^{46}$, gridExtra $^{47}$, rjags $^{48}$, segmented $^{49}$, seqinr $^{50}$, sjPlot $^{51}$, bbmle $^{52}$, coda $^{53}, \mathrm{msa}^{54}$, ape $^{55}$, ggtree $^{56}$.

\section{Accession Numbers}

207

Genome sequences of all virus isolates have been deposited in GenBank with the accession numbers MG845887 to MG845895.

\section{Virus Isolation}


212 A total of nine virus strains were isolated from untreated domestic sewage. By sequencing their

213 whole genomes, six isolates were identified as serotype coxsackievirus B5, two as serotype

214 coxsackievirus B4 and one as serotype coxsackievirus B1. All CVB5 isolates belong to genotype IV, 215 which mostly contains viruses isolated after 1984, whereas the Faulkner strain, which was isolated in 2161952 , belongs to genotype $\mathrm{I}^{57}$. The different isolates were named according to the isolation date and 217 the first letter of the city they were isolated from (Table 1).

218 The genetic distance between isolates, determined by comparison of their VP1 genes, is illustrated in 219 a neighbor-joining tree (Figure 1). All CVB5 isolates exhibited $79.1-99.4 \%$ pairwise identity, whereas they shared $76.8-81.7 \%$ with the CVB5 Faulkner strain (Table S2). This discrepancy can be explained by the different year of isolation of the CVB5 isolates and the Faulkner strain (2015 versus 1952 respectively), and their different genotypes (IV versus I, respectively). The CVB4 isolates had $88.1 \%$ identity among each other, and shared 63.4-66.1\% with CVB5 isolates. The single CVB1 isolate (CVB1L071615) shared 61.3-67.6\% identity with all other viruses. Finally, E11 exhibited the greatest genetic distance, sharing only 59.3-62.2\% of its VP1 gene with the other viruses considered. At the protein level, the pairwise identity among CVB5 environmental isolates corresponded to 99\%, but was only 92 and $90 \%$ when compared to CVB4 isolates and E11, respectively (Table S3). The distribution of isolated serotypes is consistent with literature reporting that CVB5 is the most recurrent enterovirus, with high isolation frequencies ${ }^{58}$ and high annual prevalence ${ }^{59,60}$.

\section{Inactivation kinetics}

The distributions of the inactivation rate constants for all viruses and treatment methods studied is shown in Figure 2. The values of the inactivation rate constants and associated statistics, along with the inactivation curves, are shown in the Supporting Information (Table S4 and Figures S1-S5). From these data it is evident that variability exists among different viruses in their susceptibility to disinfectants, and that the extent of this variability differs between the inactivation methods tested. An ANCOVA analysis furthermore confirmed that the rate constants differed between virus strains, 
but were mostly consistent between experimental replicates of a single virus, even if stock solutions produced by different amplifications were used (see Supporting Information).

$U V$ and Sunlight inactivation. Inactivation by $U_{254}$ and sunlight were first-order with respect to fluence (Figures S1 and S2). The mean $U_{254}$ inactivation rate constants $\left(k_{u v}\right)$ for all enteroviruses tested ranged from 0.28 to $0.38 \mathrm{~mJ}^{-1} \cdot \mathrm{cm}^{2}$ (Figure $2 \mathrm{~A}$ ). These rate constants are consistent with those previously reported for different enteroviruses (Hijnen et al. 2006, and references therein ${ }^{61}$ ). If only strains of the CVB5 serotype are considered, the variability is smaller, with mean values of $k_{U V}$ ranging from 0.32 to $0.37 \mathrm{~mJ}^{-1} \cdot \mathrm{cm}^{2}$. MS2 was more resistant to $\mathrm{UV}_{254}\left(0.15 \mathrm{~mJ}^{-1} \cdot \mathrm{cm}^{2}\right)$ than all enteroviruses.

Inactivation by sunlight led to a wider distribution of inactivation rate constants. Specifically, the mean $k_{\text {sun }}$ values for the different enteroviruses spanned a range from $1.3 \cdot 10^{-3}$ to $9.0 \cdot 10^{-3} \mathrm{~mJ}^{-1} \cdot \mathrm{cm}^{2}$

(Figure 2C). These values correspond well to those previously reported for the inactivation of PV3 by simulated sunlight in $\mathrm{PBS}^{62}$. The variability of inactivation by sunlight was slightly reduced if only CVB5 strains were considered, with the most resistant strain (Faulkner) exhibiting a mean rate constant of $3.2 \cdot 10^{-3} \mathrm{~mJ}^{-1} \cdot \mathrm{cm}^{2}$. As for $\mathrm{UV}_{254}, \mathrm{MS} 2$ was more resistant than any of the enteroviruses tested.

The differences in susceptibility of the different viruses to $U V_{254}$ and sunlight can be partly explained by the difference in the genome length. Given that all viruses tested have the same genome type (ssRNA), and assuming a constant rate of genome lesion formation during exposure to radiation, a longer genome will result in a higher number of lesions per genome ${ }^{63}$. Correspondingly, if $k$ of each virus is normalized by its respective genome length, the variability in $k$ decreases, though does not disappear (Figure S6).

Free chlorine and chlorine dioxide. Inactivation by FC was first-order with respect to dose (Figure S3), and yielded enterovirus inactivation rate constants $\left(k_{F C}\right)$ ranging from 0.8 to $8.0 \mathrm{mg}^{-1} \cdot \mathrm{min}^{-1} \cdot \mathrm{L}$ (Figure 
262 Variability was also observed within the different CVB5 strains, for which the $k_{F C}$ ranged from 0.8 to

$2634.9 \mathrm{mg}^{-1} \cdot \mathrm{min}^{-1} \cdot \mathrm{L}$. This range also includes FC inactivation rates constants of CVB5 Faulkner determined 264 by others under similar experimental conditions ${ }^{64}$. The $k_{F C}$ of $\mathrm{MS} 2$, which corresponded to $5.9 \mathrm{mg}^{-}$ $26{ }^{1} \cdot \min ^{-1} \cdot \mathrm{L}$, fell within the upper range of enteroviruses.

266 In contrast to $\mathrm{FC}$, inactivation by $\mathrm{ClO}_{2}$ deviated from first-order and exhibited a tail at higher $\mathrm{ClO}_{2}$ 267 doses (Figure S4). The earliest onset of a tail occurred at a $\mathrm{ClO}_{2}$ dose of approximately $0.5 \mathrm{mg} \cdot \mathrm{min} \cdot \mathrm{L}^{-1}$. 268 Tailing could not be attributed to $\mathrm{ClO}_{2}$ depletion, as the $\mathrm{ClO}_{2}$ concentration was approximately 269 constant throughout the experiment (see Experimental Section). Tailing during $\mathrm{ClO}_{2}$ disinfection has 270 frequently been reported and has been attributed to various causes including virus aggregation ${ }^{34}$, 271 heterogeneity of the virus population ${ }^{65}$, or the accumulation of oxidation products that form a 272 protective layer around the residual infective viruses ${ }^{66}$. Aggregation was not observed among the 273 viruses studied herein (see Experimental Section), which rules out this feature as a cause of tailing. 274 To determine $k_{\mathrm{CIO} 2}$, only the rapid, initial portion of the inactivation curve was considered ( $k_{1}$ in 275 equation 3). Values of $k_{\mathrm{ClO} 2}$ for all viruses tested ranged from 16.4 to $46.1 \mathrm{mg}^{-1} \cdot \mathrm{min}^{-1} \cdot \mathrm{L}$ (Figure $2 \mathrm{G}$ ). A 276 slightly smaller range in mean $k_{\mathrm{ClO} 2}$ values was observed among strains of CVB5, which ranged from 27716.4 to $35.1 \mathrm{mg}^{-1} \cdot \mathrm{min}^{-1} \cdot \mathrm{L}$. The $k_{\mathrm{ClO} 2}$ for MS2 $\left(37.9 \mathrm{mg}^{-1} \cdot \mathrm{min}^{-1} \cdot \mathrm{L}\right)$ fell within the upper range of the 278 enteroviruses.

279 For $\mathrm{E} 11$, it was previously found that $\mathrm{FC}$ and $\mathrm{ClO}_{2}$ act on both the viral proteins and genome. 280 Differences in the chemical reactivity of the viral proteins or genome toward $\mathrm{FC}$ and $\mathrm{ClO}_{2}$ may thus explain some of the variability in the observed inactivation rate constants of the viruses considered in the present study. The abundance of readily oxidizable, solvent-exposed amino acids on the structural proteins was strongly correlated with $k_{F C}$ (Pearson's $\left.r=0.79\right)$, but only weakly and inversly with $k_{\mathrm{ClO} 2}$ (Pearson's $r=-0.22$; Figure S7). At the genome level, guanosine is the most reactive nucleotide toward both $\mathrm{FC}$ and $\mathrm{ClO}_{2}{ }^{68,69}$, and the degradation of the $5^{\prime}$ non-coding region was previously found to correlate with inactivation by $\mathrm{ClO}_{2}{ }^{70}$. Here, we therefore explored if the 
guanosine content of the $5^{\prime}$ non-coding region could be used as an indicator of a virus susceptibility

to $\mathrm{FC}$ or $\mathrm{ClO}_{2}$. A moderate correlation with the respective inactivation rate constants was observed

for FC (Pearson's $r=0.51$ ), and a weak one with $\mathrm{ClO}_{2}$ (Pearson's $r=0.31$; Figure S8). To improve these

correlations, further information on the RNA and protein secondary and tertiary structure may be

needed. This analysis indicates that kinetics of inactivation by FC may be influenced by the chemical

virus composition, whereas inactivation by $\mathrm{ClO}_{2}$ is mainly linked to biological factors, such as the use of different host cell receptor sites or different recombination efficiencies.

Heat. Similar to inactivation by $\mathrm{ClO}_{2}$, exposing the different enteroviruses to a temperature of $55^{\circ} \mathrm{C}$ resulted in tailing inactivation curves (Figure S5). The onset of the tail varied greatly between the different viruses, ranging from 15 seconds of heat exposure (CVB5-Faulkner, CVB5-L030315, CVB5L061815, CVB4-M063015, and E11, Figure S5) to no observable tail throughout the experimental time considered. For the early tailing viruses, only the linear part of the inactivation curve was considered to determine the inactivation rate constant $k_{\text {heat }}\left(\mathrm{k}_{1}\right.$ in equation 3$)$. The mean values of $k_{\text {heat }}$ for the enteroviruses considered ranged from 0.15 to $2.11 \mathrm{sec}^{-1}$. The corresponding range for only CVB5 strains was slightly narrower, reaching from mean values of 0.16 to $0.63 \mathrm{sec}^{-1}$, whereas MS2 displayed a much lower mean value of $k_{\text {heat }}$ of $0.006 \mathrm{sec}^{-1}$ (Figure 2I).

Changes in capsid amino acid residues have been previously linked to increases in the thermal stability of foot-and-mouth disease virus, another virus in the Picornaviridae family ${ }^{71}$. A similar effect may be caused by small differences in the amino acid content of the structural virus proteins (Table S2), which may cause the observed differences in $k_{\text {heat }}$ among the different enteroviruses considered.

307 Furthermore, at the treatment temperature used $\left(55^{\circ} \mathrm{C}\right)$, capsid disruption followed by RNA escape is 308 a probable reason for the inactivation of enteroviruses ${ }^{72,73}$. Heat resistance is thus likely linked to the strength of the interaction between the virus capsid subunits ${ }^{73}$, which may differ among the different serotypes and strains. A corresponding analysis is the subject of an ongoing study in our laboratory. 
312 The different enterovirus strains considered herein exhibit similar genomic and protein features

313 (Tables S2 and S3), yet the different serotypes are still genetically distant from one another (Figure

314 1). To determine how this genetic diversity is reflected in disinfection susceptibility, the viruses were

315 grouped by serotype; for CVB4 and CVB5, which contained more than one strain, a mixture

316 distribution of $k$ values was established (Figures 2B, D, F, H, and J). Bayesian analysis was then

317 applied to quantify the probability that a given serotype is more or less resistant than any of the

318 other serotypes tested. Because the different disinfectants inactivate viruses via different

319 mechanisms ${ }^{74}$, these analyses were carried out for each disinfectant individually, to capture

320 mechanism- or disinfectant-specific variability in virus resistance.

321

322

323

324

325

326

327

$U V_{254}$ and Sunlight inactivation. Comparisons between the four different serotypes revealed that despite their similarity in genome length and composition, their sensitivities to $U_{254}$ nevertheless differed (Figures 2B). Specifically, CVB1 exhibited a >99\% probability of being more resistant than the other serotypes tested, whereas the rate constants for the other serotypes grouped more closely. . However, while the observed differences in $k_{u v}$ between CVB1 and the other enterovirus serotypes were quantifiable, they are of little practical significance: to achieve a $4-\log _{10}$ inactivation, CVB1 required a $U_{254}$ dose of $32.5 \mathrm{~mJ} \cdot \mathrm{cm}^{-2}$, whereas the most susceptible serotype (CVB4) required a similar dose of $25.3 \mathrm{~mJ} \cdot \mathrm{cm}^{-2}$ (Table S4).

A very different resistance pattern was observed for inactivation by sunlight (Figures 2D). CVB5 was the least resistant virus, with a $>85 \%$ probability of being less resistant than any other serotype, whereas E11 had a $>99 \%$ probability of being the most resistant. In contrast to $\mathrm{UV}_{254}$ inactivation, this variability translates into a substantial differences in the environmental persistence in sunlit waters, or the inactivation performance by devices relying on disinfection by solar UVB: to achieve a 4- $\log _{10}$ inactivation, CVB5 required a UVB dose of $1369 \mathrm{~mJ} \cdot \mathrm{cm}^{-2}$, which is the equivalent of 2.3 days of solar UVB exposure at the equator. To achieve the same $\log _{10}$ reduction, E11 required a dose of 5430 $\mathrm{mJ} \cdot \mathrm{cm}^{-2}$, which corresponds to approximately 9.1 days of solar UVB exposure at the equator. 
337 The discrepant resistance patterns of viruses toward $\mathrm{UV}_{254}$ and sunlight indicates that the mechanism 338 of action of these two inactivating treatments differ. This can be rationalized by a number of causes. 339 First, the wavelength spectrum and fluence rates of these two methods are different, and thus the 340 type and yield of lesions to the viral genome likely differs ${ }^{75}$. Second, differences in thermal stability of 341 the viruses may influence the observed inactivation rates, in particular if thermal inactivation during 342 the lengthy sunlight experiments synergistically promoted inactivation by sunlight. And finally, 343 inactivation by sunlight may involve a greater portion of protein damage compared to $U_{254}$, which 344 may contribute to inactivation ${ }^{76}$.

345 Free chlorine and chlorine dioxide. $\mathrm{FC}$ and $\mathrm{ClO}_{2}$ treatment varied in their effect on the different 346 enterovirus serotypes (Figures $2 \mathrm{~F}, 2 \mathrm{H}$ ). For inactivation by $\mathrm{FC}, \mathrm{E} 11$ had a $>98 \%$ probability of being 347 less resistant than the other serotypes, whereas CVB1 was the most resistant serotype (>85\% 348 probability). The susceptibility of the different serotypes results in considerable differences in the FC 349 dose to achieve a $4-\log _{10}$ inactivation: E11 required a dose of $1.1 \mathrm{mg} \cdot \mathrm{min} \cdot \mathrm{L}^{-1}$ while $\mathrm{CVB} 1 \mathrm{required}$ a dose of $6.4 \mathrm{mg} \cdot \mathrm{min} \cdot \mathrm{L}^{-1}$.

For disinfection by $\mathrm{ClO}_{2}$, CVB4 and CVB5 had high probabilities (>99\% and $>92 \%$, respectively) of being more resistant than CVB1 or E11. The latter two serotypes exhibited comparable susceptibilities to $\mathrm{ClO}_{2}$. This latter finding is surprising, as CVB1 was the most resistant serotype toward FC. The observed extent of variability in disinfection kinetics among serotypes did not lead to significant differences in the $\mathrm{ClO}_{2}$ requirements at low levels of inactivation. Specifically, the most resistant serotype $(C V B 4)$ required a dose of $0.11 \mathrm{mg} \cdot \mathrm{min} \cdot \mathrm{L}^{-1}$ for a $1-\log _{10}$ inactivation, and the most

357 susceptible serotype (CVB1) a dose of $0.05 \mathrm{mg} \cdot \mathrm{min} \cdot \mathrm{L}^{-1}$. These dose requirements, however, differ 358 more dramatically if higher levels of inactivation are considered, as for some serotypes and 359 environmental isolates, a 4- $\log _{10}$ inactivation could not be achieved due to tailing of the disinfection curve (Figure S4 and Table S3). 
361

362

363

364

Heat. Inactivation by heat was the least effective against CVB1 and CVB5, which were more thermally stable than the other two serotype tested with $>99 \%$ probability (Figure $2 \mathrm{~J}$ ). The most heat sensitive serotype was CVB4, though the two strains contained in this serotype exhibited vastly different susceptibilities to heat.

In summary, the results of this study demonstrate pronounced variability in disinfection susceptibility among four different enterovirus serotypes. While disinfection requirements were fairly homogeneous across serotypes and strains for $\mathrm{UV}_{254}$, the requirements for sunlight, $\mathrm{FC}, \mathrm{ClO}_{2}$ and heat for a given enterovirus serotype were not predictive of that of other serotypes.

\section{Assessment of enterovirus lab strains or MS2 as surrogates for the disinfection of environmental} isolates

Many virus disinfection studies to date rely on laboratory strains ${ }^{9,64,77-81}$, which are easy to obtain because they are commercially available. Results from such studies should be interpreted with caution, since we showed here that a single laboratory strain of a single serotype may not accurately reflect the inactivation kinetics of other serotypes (Figure 2). Additionally, as illustrated below, we here show that even the lab strain of a specific serotype (here CVB5 Faulkner strain) may not be a suitable representative for environmental isolates of the same serotype. Specifically, inactivation kinetics of different isolates of CVB5 by sunlight and heat were only poorly represented by the corresponding laboratory strain. Bayesian analysis demonstrated that the Faulkner strain had a > $99 \%$ probability of being more resistant to solar disinfection and less resistant to heat compared to the environmental isolates (Figure 3). This indicates that the lab strain is not a good surrogate to assess the environmental stability of isolates.

The Faulkner strain was also not a suitable surrogate for the inactivation of most environmental CVB5 isolates by oxidants and $\mathrm{UV}_{254}$. Bayesian analysis confirmed that all but one of the CVB5 isolates (CVB5-L060815) had a high (>99\%) probability of being more resistant to FC than the Faulkner strain (Figure 3), and exhibited inactivation rate constants that were up to five times lower than the 
Faulkner strain (Table S4). Similarly, all but two isolates (CVB5-L061815 and CVB5-L070215) had a high (90\%) probability of being more resistant to $\mathrm{ClO}_{2}$ compared to the Faulkner strain (Figure 3), though the differences in inactivation rate constants were less pronounced compared to FC (Table S4). Finally, three of the environmental isolates (CVB5-L061815, CVB5-L070215 and CVB5-L030315) were more resistant to $\mathrm{UV}_{254}$ than the Faulkner strain, while others (CVB5-L060815, CVB5-L070915 and CVB5-M063015) had similar probabilities of being more or less resistant (Figure 3).

Our data thus imply that disinfection studies based on lab strains may not be representative of many viruses circulating in the environment. Reliance on laboratory strains may therefore lead to the underestimation of actual treatment requirements. This latter point is emphasized in Figure 4, which compares our data with the US EPA's recommended $C t$ value for a $4 \log _{10}$ inactivation of viruses by FC at $20^{\circ} \mathrm{C}^{82}$. While both laboratory strains (E11 Gregory and CVB5 Faulkner) tested fall well below the EPA Ct requirement, several of the environmental isolates exceed it, such that the EPA recommendation would not guarantee a $4-\log _{10}$ reduction for these viruses.

Bacteriophages such as MS2 have also been proposed as surrogates for the disinfection of enteric viruses $^{20}$, since they have similar properties as enteric viruses ${ }^{83}$. This approach is popular because phages are easier and cheaper to handle than actual human viruses. However, as is evident from Figure 2 and confirmed by Bayesian analysis (Figure S9), MS2 is not always a good surrogate for the inactivation kinetics of enteroviruses present in the treatment systems. Specifically, MS2 was less resistant to inactivation by $\mathrm{FC}$ and $\mathrm{ClO}_{2}$ than many of the coxsackieviruses studied, though it was representative of, or even more resistant than, E11. If MS2 is used as an indicator for virus inactivation by $\mathrm{FC}$ or $\mathrm{ClO}_{2}$, the disinfection requirements of many Enterovirus $B$ strains would thus be underestimated. In contrast, MS2 can be considered a good conservative surrogate for Enterovirus $B$ inactivation by heat, $\mathrm{UV}_{254}$ and sunlight, as it was significantly more resistant to these treatments than any enterovirus studied. As discussed above, the greater resistance of MS2 to radiation can be partly explained by the difference in the genome length of MS2 (3569 bases) compared to 
411

412

enteroviruses (ca. 7400 bases). However, even if corrected for genome length (Figure S6), MS2 still mostly underestimated enterovirus inactivation by $\mathrm{UV}_{254}$ and sunlight.

Overall, this analysis reveals that neither the lab strains nor MS2 bacteriophage can satisfactorily model inactivation behavior of all Enterovirus $B$ species. Given the significant variability of inactivation kinetics among commonly occurring enteroviruses, we therefore recommend that future disinfection studies be conducted based on a range of viruses that include environmental isolates, as well as different serotypes.

\section{SUPPORTING INFORMATION}

The Supporting Information is available free of charge on the ACS Publications website at http://pubs.acs.org. Additional information on chemicals, laboratory virus strains, plaque assays, Bayesian analysis and ANCOVA analysis; tables with primer information, nucleotide and protein pairwise identities of all viruses, $k$ values and $C t$ values for 1 to 4 - $\log _{10}$ inactivation; plots showing the inactivation curves for all virus-disinfectant combinations; $k_{U v}$ and $k_{\text {sun }}$ normalized by genome length;

a correlation analysis of oxidizable amino acids or guanosine content with $k_{F C}$ and $k_{\mathrm{ClO}^{\circ} 2}$; and the Bayesian comparison between enteroviruses and MS2.

\section{ACKNOWLEDGEMENT}

This work was funded by the Swiss National Science Foundation (project numbers 31003A_138319 and 31003A_163270). We thank Paige Novak for providing the Minneapolis wastewater sample and Virginie Bachmann for her laboratory assistance.

\section{REFERENCES}

(1) Malik, Y. S.; Matthijnssens, J. Enteric viral infection in human and animal. VirusDisease 2014, $25,145-146$.

(2) Hurst, C. J.; Benton, W. H.; McClellan, K. A. Thermal and water source effects upon the 
stability of enteroviruses in surface freshwaters. Can. J. Microbiol. 1989, 35, 474-480.

(3) Pepper, I.; Gerba, C. P.; Gentry, T. J. Environmental Microbiology; 2015.

(4) Khetsuriani, N.; Lamonte-Fowlkes, A.; Oberst, S.; Pallansch, M. A. Enterovirus surveillance United States, 1970-2005. Morb. Mortal. Wkly. Rep. Surveill. Summ. 2006, 55, 1-20.

(5) USEPA. Drinking Water Contaminant Candidate List 4. Fed. Regist. 2016, 81, 81099-81114.

(6) Oberste, M. S.; Maher, K.; Kilpatrick, D. R.; Pallansch, M. A. Molecular evolution of the human enteroviruses: correlation of serotype with VP1 sequence and application to picornavirus classification. J. Virol. 1999, 73, 1941-1948.

(7) Caro, V.; Guillot, S.; Delpeyroux, F.; Crainic, R. Molecular strategy for "serotyping" of human enteroviruses. J. Gen. Virol. 2001, 82, 79-91.

(8) Petterson, S. R.; Stenström, T. A. Quantification of pathogen inactivation efficacy by free chlorine disinfection of drinking water for QMRA. J. Water Health 2015, 13, 625-644.

(9) Cromeans, T. L.; Kahler, A. M.; Hill, V. R. Inactivation of adenoviruses, enteroviruses, and murine norovirus in water by free chlorine and monochloramine. Appl. Environ. Microbiol. 2010, 76, 1028-1033.

(10) Payment, P.; Tremblay, M.; Trudel, M. Relative resistance to chlorine of poliovirus and coxsackievirus isolates from environmental sources and drinking water. Appl. Environ. Microbiol. 1985, 49, 981-983.

(11) Harakeh, S. The behavior of viruses on disinfection by chlorine dioxide and other disinfectants in effluent. FEMS Microbiol. Lett. 1987, 44, 335-341.

(12) Floyd, R.; Sharp, D. G. Inactivation by Chlorine of Single poliovirus in water. Environ. Sci. Technol. 1979, 13, 438-442.

(13) Sharp, D. G.; Leong, J. Inactivation of poliovirus I (Brunhilde) single particles by chlorine in water. Appl. Environ. Microbiol. 1980, 40, 381-385.

(14) Gerba, C. P.; Gramos, D. M.; Nwachuku, N. Comparative Inactivation of Enteroviruses and Adenovirus 2 by UV Light. Appl. Environ. Microbiol. 2002, 68, 5167-5169.

(15) Heaselgrave, W.; Kilvington, S. The efficacy of simulate solar disinfection (SODIS) against coxsackievirus, poliovirus and hepatitis A virus. J. Water Health 2012, 10, 531-538.

(16) Bates, R. C.; Shaffer, P. T. B.; Sutherland, S. M. Development of Poliovirus Having Increased Resistance to Chlorine Inactivation. Appl. Environ. Microbiol. 1977, 34, 849-853.

(17) Shaffer, P. T. B.; Metcalf, T. G.; Sproul, O. J. Chlorine resistance of poliovirus isolants recovered from drinking water. Appl. Environ. Microbiol. 1980, 40, 1115-1121.

(18) Carratalà, A.; Shim, H.; Zhong, Q.; Bachmann, V.; Jensen, J. D.; Kohn, T. Experimental adaptation of human echovirus 11 to ultraviolet radiation leads to tolerance to disinfection and resistance to ribavirin. Virus Evol. 2017, 3, vex035.

(19) Tree, J. A.; Adams, M. R.; Lees, D. N. Chlorination of Indicator Bacteria and Viruses in Primary Sewage Effluent. Appl. Environ. Microbiol. 2003, 69, 2038-2043.

(20) WHO. Evaluating Household Water Treatment Options : Health-Based Targets and Microbiological Performance Specifications. NML Classif. WA 675 2011, 1-68.

(21) Zhong, Q.; Carratalà, A.; Ossola, R.; Bachmann, V., Kohn, T. Cross-resistance of UV- or chlorine dioxide-resistant echovirus 11 to other disinfectants. Front. Environ. Microbiol. Press.

(22) Aw, T. G.; Howe, A.; Rose, J. B. Metagenomic approaches for direct and cell culture evaluation of the virological quality of wastewater. J. Virol. Methods 2014, 210, 15-21.

(23) Lewis, G. D.; Metcalf, T. G. Polyethylene glycol precipitation for recovery of pathogenic 
viruses, including hepatitis A virus and human rotavirus, from oyster, water, and sediment samples. Appl. Environ. Microbiol. 1988, 54, 1983-1988.

(24) Shieh, Y. S.; Wait, D.; Tai, L.; Sobsey, M. D. Methods to remove inhibitors in sewage and other fecal wastes for enterovirus detection by the polymerase chain reaction. J. Virol. Methods $1995,54,51-66$.

(25) Calgua, B.; Rodriguez-Manzano, J.; Hundesa, A.; Suñen, E.; Calvo, M.; Bofill-Mas, S.; Girones, R. New methods for the concentration of viruses from urban sewage using quantitative PCR. $J$. Virol. Methods 2013, 187, 215-221.

(26) Carratalà, A.; Calado, A. D.; Mattle, M. J.; Meierhofer, R.; Luzi, S.; Kohn, T. Solar disinfection of viruses in polyethylene terephthalate bottles. Appl. Environ. Microbiol. 2016, 82, 279-288.

(27) Oberste, M. S.; Nix, W. A.; Maher, K.; Pallansch, M. A. Improved molecular identification of enteroviruses by RT-PCR and amplicon sequencing. J. Clin. Virol. 2003, 26, 375-377.

(28) Pickett, B. E.; Sadat, E. L.; Zhang, Y.; Noronha, J. M.; Squires, R. B.; Hunt, V.; Liu, M.; Kumar, S.; Zaremba, S.; Gu, Z.; et al. ViPR: An open bioinformatics database and analysis resource for virology research. Nucleic Acids Res. 2012, 40, 593-598.

(29) Kang, Y.; Chatterjee, N. K.; Nodwell, M. J.; Yoon, J.-W. Complete nucleotide sequence of a strain of coxsackie B4 virus of human origin that induces diabetes in mice and its comparison with nondiabetogenic coxsackie B4 JBV strain. J. Med. Virol. 1994, 44, 353-361.

(30) Kearse, M.; Moir, R.; Wilson, A.; Stones-Havas, S.; Cheung, M.; Sturrock, S.; Buxton, S.; Cooper, A.; Markowitz, S.; Duran, C.; et al. Geneious Basic: An integrated and extendable desktop software platform for the organization and analysis of sequence data. Bioinformatics 2012, 28, 1647-1649.

(31) Edgar, R. C. MUSCLE: Multiple sequence alignment with high accuracy and high throughput. Nucleic Acids Res. 2004, 32, 1792-1797.

(32) Saitou, N.; Nei, M. The neighbour-joining method: a new method for reconstructing phylogenetic trees. Mol Biol Evo 1987, 4, 406-425.

(33) Pecson, B. M.; Martin, L. V.; Kohn, T. Quantitative PCR for determining the infectivity of bacteriophage MS2 upon inactivation by heat, UV-B radiation, and singlet oxygen: Advantages and limitations of an enzymatic treatment to reduce false-positive results. Appl. Environ. Microbiol. 2009, 75, 5544-5554.

(34) Mattle, M. J.; Kohn, T. Inactivation and tailing during UV254 disinfection of viruses: Contributions of viral aggregation, light shielding within viral aggregates, and recombination. Environ. Sci. Technol. 2012, 46, 10022-10030.

(35) Kott, Y. Estimation of low numbers of Escherichia coli bacteriophage by use of the most probable number method. Appl. Microbiol. 1966, 14, 141-144.

(36) Rahn, R. Potassium lodide as a Chemical Actinometer for $254 \mathrm{~nm}$ Radiation : Use of lodate as an Electron Scavenger. Photochem. Photobiol. 1997, 66, 450-455.

(37) Rahn, R. O.; Bolton, J.; Stefan, M. I. The iodide/iodate actinometer in UV disinfection: determination of the fluence rate distribution in UV reactors. Photochem. Photobiol. 2006, 82, 611-615.

(38) Beckmann, M.; Václavík, T.; Manceur, A. M.; Šprtová, L.; von Wehrden, H.; Welk, E.; Cord, A. F. glUV: A global UV-B radiation data set for macroecological studies. Methods Ecol. Evol. 2014, 5, 372-383.

(39) Clesceri, L. S.; Greenberg, A. E.; Trussell, R. R.; Association., A. P. H.; Association., A. W. W.; Federation., W. P. C. Standard methods for the examination of water and wastewater; American Public Health Association: Washington, DC, 1989. 
(40) Sigstam, T.; Gannon, G.; Cascella, M.; Pecson, B. M.; Wigginton, K. R.; Kohn, T. Subtle differences in virus composition affect disinfection kinetics and mechanisms. Appl. Environ. Microbiol. 2013, 79, 3455-3467.

(41) Chick, H.; Martin, C. J. The Principles involved in the Standardisation of Disinfectants and the Influence of Organic Matter upon Germicidal value. Epidemiol. Infect. 1908, 8, 654-697.

(42) Watson, H. E. A Note on the Variation of the Rate of Disinfection with Change in the Concentration of the Disinfectant. J. Hyg. (Lond). 1908, 8, 536-542.

(43) Haas, C. N. Estimation of microbial densities from dilution count experiments. Appl. Environ. Microbiol. 1989, 55, 1934-1942.

(44) R Development Core Team. R Software. R: A Language and Environment for Statistical Computing, 2013.

(45) Plummer, M. JAGS: just another Gibbs sampler. In Proceedings of the 3rd International Workshop on Distributed Statistical Computing (DSC 2003); 2005.

(46) Wickham, H. ggplot2 Elegant Graphics for Data Analysis. Media 2009, 35, 211.

(47) Auguie, B. gridExtra: Miscellaneous Functions for “Grid” Graphics, 2016.

(48) Plummer, M. rjags: Bayesian graphical models using MCMC. R package, 2016, 19.

(49) Muggeo, V. M. R. segmented: An R package to Fit Regression Models with Broken-Line Relationships. $R$ News 2008, 8, 20-25.

(50) Charif, D.; Lobry, J. R.; Necsulea, A.; Palmeira, L.; Perriere, G.; Penel, M. S. Package seqinr. $R$ Packag. 2015, 218.

(51) Lüdecke, D. sjPlot: Data Visualization for Statistics in Social Science. R Packag. 2017.

(52) Bolker, B.; Team, R. D. C. bbmle: Tools for general maximum likelihood estimation. $R$ package, 2013, 0-28.

(53) Best, N. G.; Cowles, K.; Vines, K.; Plummer, M. Package “coda.” Citeseer 2010.

(54) Bodenhofer, U.; Bonatesta, E.; Horejš-Kainrath, C.; Hochreiter, S. msa: an R package for multiple sequence alignment. Bioinformatics 2015, 31, 3997-3999.

(55) Paradis, E.; Claude, J.; Strimmer, K. APE: analyses of hylogenetics and evolution in R language. Bioinformatics 2004, 20, 289-290.

(56) Yu, G.; Smith, D. K.; Zhu, H.; Guan, Y.; Lam, T. T. Y. ggtree: an r package for visualization and annotation of phylogenetic trees with their covariates and other associated data. Methods Ecol. Evol. 2017, 8, 28-36.

(57) Rezig, D.; Ben Yahia, A.; Ben Abdallah, H.; Bahri, O.; Triki, H. Molecular Characterization of Coxsackievirus B5 Isolates. J. Med. Virol. 2004, 72, 268-274.

(58) Antona, D.; Lévêque, N.; Chomel, J. J.; Dubrou, S.; Lévy-Bruhl, D.; Lina, B. Surveillance of enteroviruses in France, 2000-2004. Eur. J. Clin. Microbiol. Infect. Dis. 2007, 26, 403-412.

(59) Roth, B.; Enders, M.; Arents, A.; Pfitzner, A.; Terletskaia-Ladwig, E. Epidemiologic aspects and laboratory features of enterovirus infections in Western Germany, 2000-2005. J. Med. Virol. 2007, 79, 956-962.

(60) Trallero, G.; Avellon, A.; Otero, A.; De Miguel, T.; Pérez, C.; Rabella, N.; Rubio, G.; Echevarria, J. E.; Cabrerizo, M. Enteroviruses in Spain over the decade 1998-2007: Virological and epidemiological studies. J. Clin. Virol. 2010, 47, 170-176.

(61) Hijnen, W. a M.; Beerendonk, E. F.; Medema, G. J. Inactivation credit of UV radiation for viruses, bacteria and protozoan (oo)cysts in water: A review. Water Res. 2006, 40, 3-22. 
(62) Silverman, A. I.; Peterson, B. M.; Boehm, A. B.; McNeill, K.; Nelson, K. L. Sunlight inactivation of human viruses and bacteriophages in coastal waters containing natural photosensitizers. Environ. Sci. Technol. 2013, 47, 1870-1878.

(63) Lytle, C. D.; Sagripanti, J.-L. Predicted Inactivation of Viruses of Relevance to Biodefense by Solar Radiation. J. Virol. 2005, 79, 14244-14252.

(64) Canning, A.; Wati, S.; Keegan, A.; Middleton, D.; Shilito, D.; Bartkow, M. Validation of relationship between free chlorine dose and pathogen inactivation in drinking water. Water J. Aust. Water Assoc. 2015, 42, 65-70.

(65) Hornstra, L. M.; Smeets, P.; Medema, G. J. Inactivation of bacteriophage MS2 upon exposure to very Low concentrations of chlorine dioxide. Water Res. 2010, 45, 1847-1855.

(66) Sigstam, T.; Rohatschek, A.; Zhong, Q.; Brennecke, M.; Kohn, T. On the cause of the tailing phenomenon during virus disinfection by chlorine dioxide. Water Res. 2014, 48, 82-89.

(67) Zhong, Q.; Carratalà, A.; Ossola, R.; Bachmann, V.; Kohn, T. Cross-Resistance of UV- or Chlorine Dioxide-Resistant Echovirus 11 to Other Disinfectants. Front. Microbiol. 2017, 8, 1928.

(68) Hauchman, F. S.; Noss, C. I.; Olivieri, V. P. Chlorine dioxide reactivity with nucleic acids. Water Res. 1986, 20, 357-361.

(69) Prütz, W. A. Hypochlorous acid interactions with thiols, nucleotides, DNA, and other biological substrates. Arch. Biochem. Biophys. 1996, 332, 110-120.

(70) Jin, M.; Shan, J.; Chen, Z.; Guo, X.; Shen, Z.; Qiu, Z.; Xue, B.; Wang, Y.; Zhu, D.; Wang, X.; et al. Chlorine dioxide inactivation of enterovirus 71 in water and its impact on genomic targets. Environ. Sci. Technol. 2013, 47, 4590-4597.

(71) Rincón, V.; Rodríguez-Huete, A.; López-Argüello, S.; Ibarra-Molero, B.; Sanchez-Ruiz, J. M.; Harmsen, M. M.; Mateu, M. G. Identification of the Structural Basis of Thermal Lability of a Virus Provides a Rationale for Improved Vaccines. Structure 2014, 22, 1560-1570.

(72) Shiomi, H.; Urasawa, T.; Urasawa, S.; Kobayashi, N.; Abe, S.; Taniguchi, K. Isolation and characterisation of poliovirus mutants resistant to heating at $50^{\circ} \mathrm{C}$ for $30 \mathrm{~min}$. J. Med. Virol. 2004, 74, 484-491.

(73) Kotecha, A.; Seago, J.; Scott, K.; Burman, A.; Loureiro, S.; Ren, J.; Porta, C.; Ginn, H. M.; Jackson, T.; Perez-martin, E.; et al. Structure-based energetics of protein interfaces guides foot-and-mouth disease virus vaccine design. Nat. Struct. \&amp; Mol. Biol. 2015, 22, 788-794.

(74) Zhong, Q.; Carratalà, A.; Shim, H.; Bachmann, V.; Jensen, J. D.; Kohn, T. Resistance of Echovirus 11 to $\mathrm{ClO} 2$ Is Associated with Enhanced Host Receptor Use, Altered Entry Routes, and High Fitness. Environ. Sci. Technol. 2017, 10746-10755.

(75) Pfeifer, G. P.; You, Y.-H.; Besaratinia, A. Mutations induced by ultraviolet light. Mutat. Res. 2005, 571, 19-31.

(76) Eischeid, A. C.; Linden, K. G. Molecular indications of protein damage in adenoviruses after UV disinfection. Appl. Environ. Microbiol. 2011, 77, 1145-1147.

(77) Meschke, J. S.; Sobsey, M. D. Comparative adsorption of Norwalk virus, poliovirus 1 and F+ RNA coliphage MS2 to soils suspended in treated wastewater. Water Sci. Technol. 1998, 38, 187-189.

(78) Battigelli, D. A.; Sobsey, M. D.; Lobe, D. C. The inactivation of hepatitis A virus and other model viruses by UV irradiation. Water Sci. Technol. 1993, 27, 339-342.

(79) Black, S.; Thurston, J. A.; Gerba, C. P. Determination of Ct values for chlorine of resistant enteroviruses. J. Environ. Sci. Health. A. Tox. Hazard. Subst. Environ. Eng. 2009, 44, 336-339. 
615

616

617

618

619

620

621

622

623

624

625
(80) Kahler, A. M.; Cromeans, T. L.; Roberts, J. M.; Hill, V. R. Effects of source water quality on chlorine inactivation of adenovirus, coxsackievirus, echovirus, and murine norovirus. Appl. Environ. Microbiol. 2010, 76, 5159-5164.

(81) Kahler, A. M.; Cromeans, T. L.; Roberts, J. M.; Hill, V. R. Source water quality effects on monochloramine inactivation of adenovirus, coxsackievirus, echovirus, and murine norovirus. Water Res. 2011, 45, 1745-1751.

(82) U.S. EPA. Disinfection Profiling and Benchmarking Guidance Manual. Environ. Prot. Agency Off. Water 1999, 1-192.

(83) Schmelcher, M.; Loessner, M. J. Application of bacteriophages for detection of foodborne pathogens. Bacteriophage 2014, 4, e28137: 1-14. 
Table 1. Serotype, genus, strain, and isolation location of viruses used in this work. The environmental isolates are named according to first letter of the city (Minneapolis, Tampa, or Lausanne) and the isolation date (month/day/year).

\begin{tabular}{llllll}
\hline Name & Serotype & Genus & Location & Strain & Access.No \\
\hline MS2 & & Levivirus & Lab strain & ATCC 15597-B1 & NC001417 \\
Echovirus 11 & Echovirus 11 & Enterovirus & Lab strain & ATCC-Gregory & X80059 \\
CVB1-L071615 & Coxsackievirus B1 & Enterovirus & Lausanne & Env. isolate & MG845887 \\
CVB4-M063015 & Coxsackievirus B4 & Enterovirus & Minneapolis & Env. isolate & MG845888 \\
CVB4-T051217 & Coxsackievirus B4 & Enterovirus & Tampa & Env. isolate & MG845889 \\
CVB5-Faulkner & Coxsackievirus B5 & Enterovirus & Lab strain & ATCC-Faulkner & AF114383 \\
CVB5-L030315 & Coxsackievirus B5 & Enterovirus & Lausanne & Env. isolate & MG845890 \\
CVB5-L060815 & Coxsackievirus B5 & Enterovirus & Lausanne & Env. isolate & MG845891 \\
CVB5-L061815 & Coxsackievirus B5 & Enterovirus & Lausanne & Env. isolate & MG845892 \\
CVB5-L070215 & Coxsackievirus B5 & Enterovirus & Lausanne & Env. isolate & MG845893 \\
CVB5-L070915 & Coxsackievirus B5 & Enterovirus & Lausanne & Env. isolate & MG845894 \\
CVB5-M063015 & Coxsackievirus B5 & Enterovirus & Minneapolis & Env. isolate & MG845895 \\
\hline
\end{tabular}




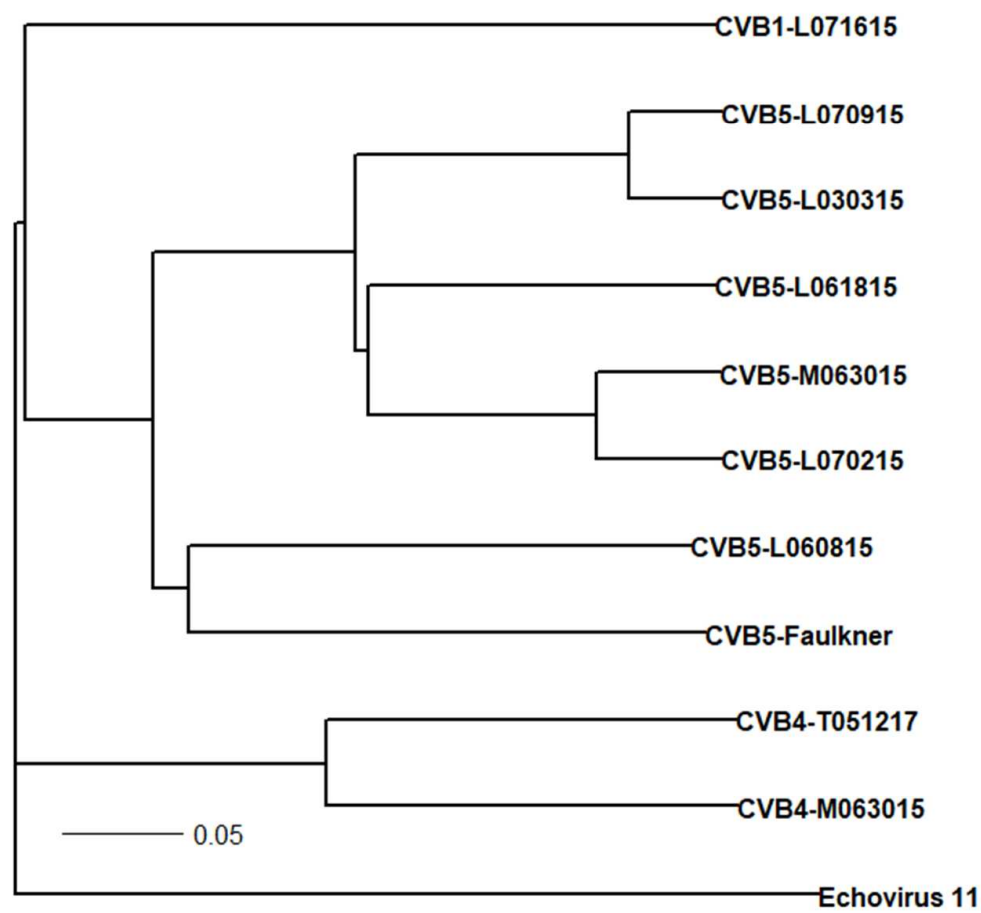

Figure 1. Unrooted neighbor joining tree of the viruses studied, built based on the virus VP1 coding region. The horizontal lines lengths are proportional to the genetic distance (see Table S2). The four serotypes represented can be clearly differentiated by their genetic distance. 

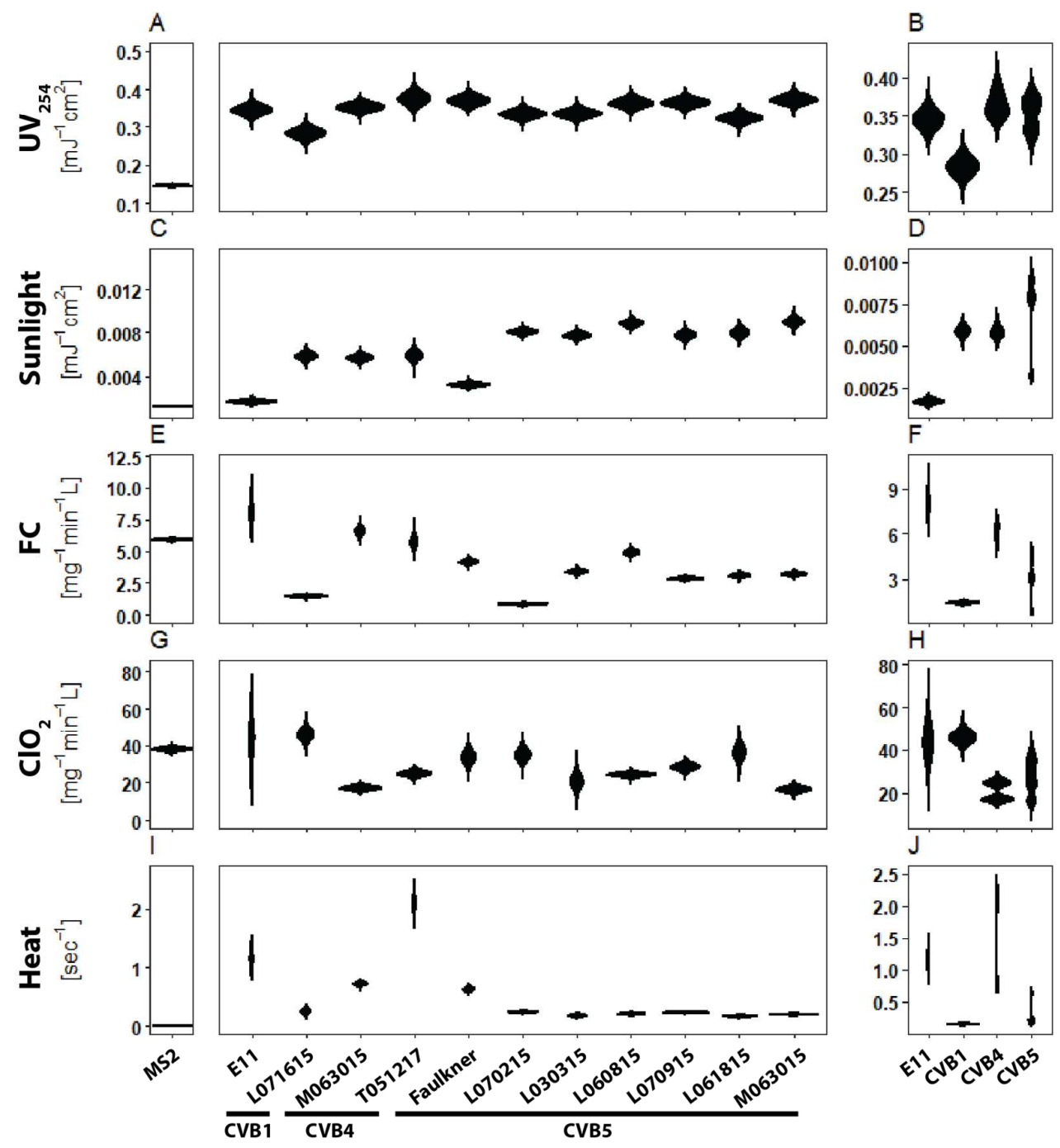

Figure 2. Violin plots of showing the distribution and probability density of rate constants $k$ associated with inactivation by $\mathrm{UV}_{254}$ (panels $\mathrm{A}$ and $\mathrm{B}$ ), sunlight ( $\mathrm{C}$ and $\left.\mathrm{D}\right), \mathrm{FC}\left(\mathrm{E}\right.$ and $\mathrm{F}$ ), $\mathrm{ClO}_{2}(\mathrm{G}$ and $\mathrm{H})$ and heat ( $\mathrm{I}$ and $\mathrm{J})$. The values of $k$ for individual viruses (MS2 and all enteroviruses) are shown in the left panels. The right panels show the mixture probability distribution of each serotype (E11, CVB1, CVB4, and CVB5), which results from the combination of the individual $k$ distributions of all viruses of a given serotype. The exact values of $k$ are given in Table S4. 

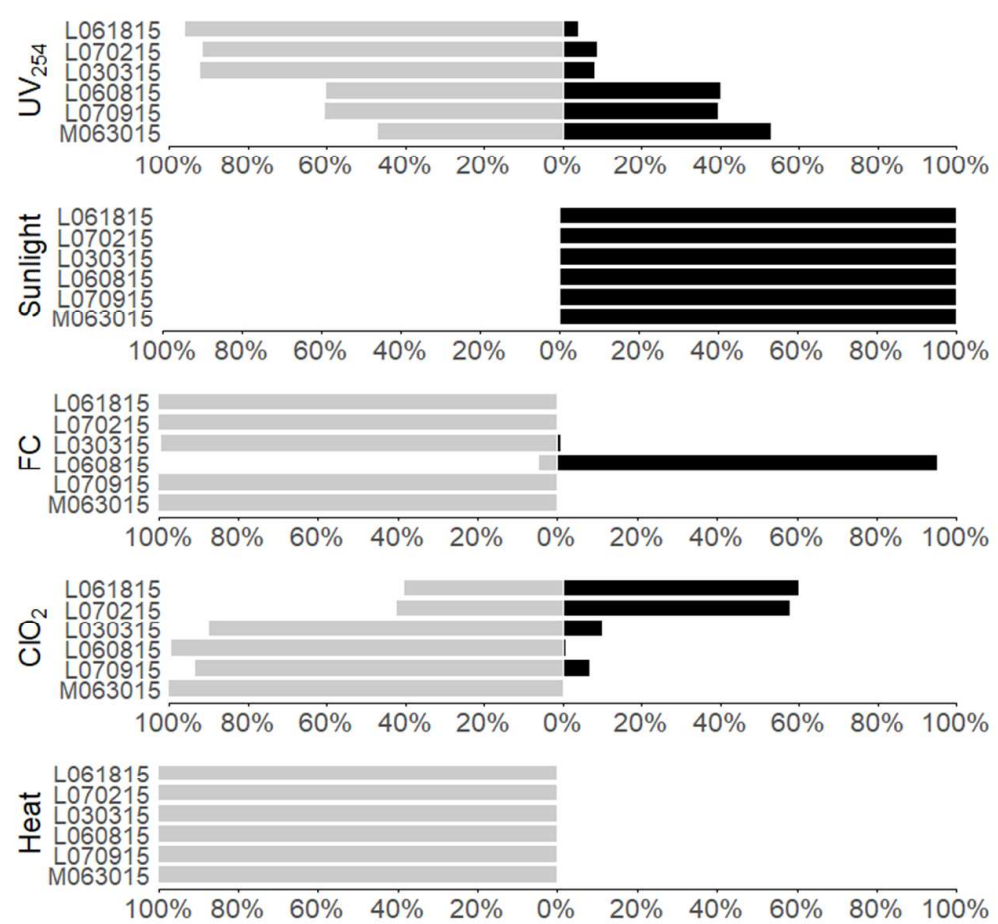

Figure 3. Bar plots showing a comparison of the probabilities of inactivation rate constants ( $k$ values) for all environmental isolates of CVB5 with the CVB5-Faulkner laboratory strain. Grey bars indicate the probability that the environmental isolate is more resistant than the Faulkner strain; black bars indicate the probability that the environmental isolate is less resistant than the Faulkner strain. 


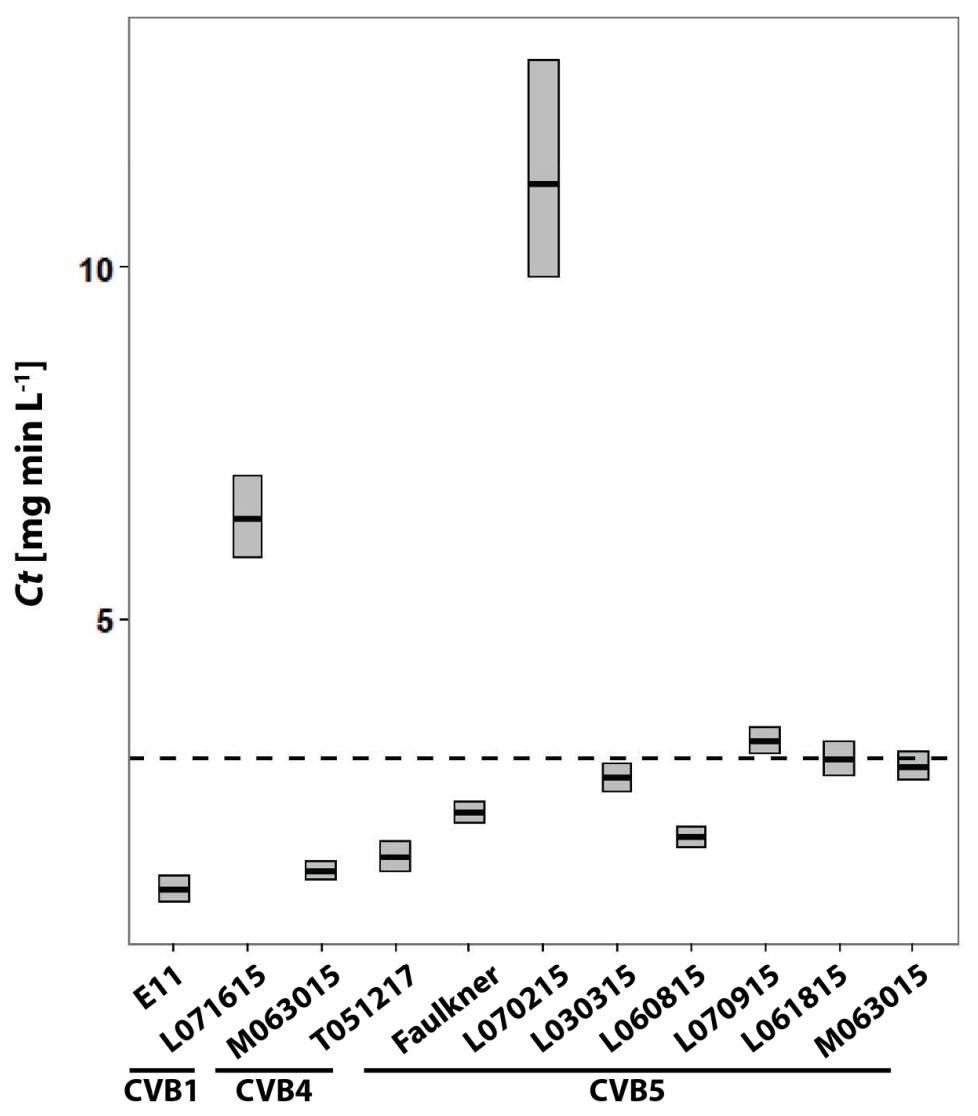

Figure 4. $C t$ values to achieve a $4-\log _{10}$ virus inactivation by FC. The dashed line corresponds to the US EPA's recommendation for $C t$ value at $20^{\circ} \mathrm{C}^{82}\left(3 \mathrm{mg} \cdot \mathrm{min} \cdot \mathrm{L}^{-1}\right)$. The bar plots indicate the mean $\mathrm{Ct}$ (black line) calculated based on the $k_{F C}$ measured herein, along with the upper and lower $95 \%$ confidence intervals (top and bottom of box). 